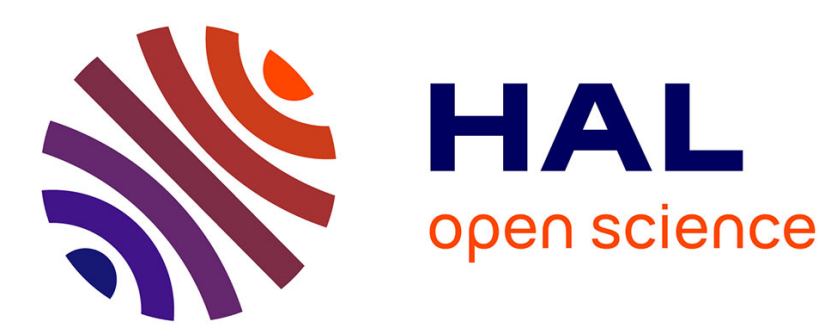

\title{
Islamic republic of Iran and Its Opposition
}

Mehrdad Vahabi, Mohajer Nasser

\section{To cite this version:}

Mehrdad Vahabi, Mohajer Nasser. Islamic republic of Iran and Its Opposition. Comparative Studies of South Asia, Africa and the Middle East, 2011, 31 (1), pp.110-119. hal-00629139

\section{HAL Id: hal-00629139 \\ https://hal.science/hal-00629139}

Submitted on 5 Oct 2011

HAL is a multi-disciplinary open access archive for the deposit and dissemination of scientific research documents, whether they are published or not. The documents may come from teaching and research institutions in France or abroad, or from public or private research centers.
L'archive ouverte pluridisciplinaire HAL, est destinée au dépôt et à la diffusion de documents scientifiques de niveau recherche, publiés ou non, émanant des établissements d'enseignement et de recherche français ou étrangers, des laboratoires publics ou privés. 
East, Vol. 31, No. 1, 2011

\title{
Islamic Republic of Iran and its Opposition
}

\author{
Nasser Mohajer and Mehrdad Vahabi
}

\begin{abstract}
This paper takes a stylized paradoxical fact of Iranian politics under the Islamic Republic of Iran as its starting point: the stark confusion between the position and a good portion of the opposition. Such a blurred frontier between 'position' and 'opposition' did not exist during the Shah's regime.

Without the decisive support of non-Islamic organizations, secular intellectuals, and political forces on the ground, the creation of a theocratic regime in Iran and its consolidation could not be realized. Now in the thirtieth anniversary of the Islamic Republic, the open opposition of many influential clergies towards the way in which government is run under the present Supreme Leader and President Ahmadinejad, provides a new episode of 'opposition' within the theocrats' circles.

To put this paradoxical fact differently, it should be emphasized that no regime in Iran's modern history has produced so much 'opposition' within its own ranks and enjoyed the loyalty of its 'oppositions' at the same time. How could this paradox be explained?

Our paper tackles this issue by describing the peculiar type of social order under the Republic Islamic of Iran as ordered anarchy or "destructive coordination". Analysing the sources of this type of coordination, we proceed in two steps. The first is to question whether there has ever been a laic or secular movement in the recent Iranian history. The second consists in defining the institutional setup and recent dynamics of the Islamic Republic of Iran as a strange, if not unique, mutant of Huntington's Praetorian state, led by 'priests' and armed religious militants.
\end{abstract}




\title{
Islamic Republic of Iran and its Opposition ${ }^{1}$
}

\author{
Nasser Mohajer and Mehrdad Vahabi
}

\section{A stylized fact of Iranian politics}

The present paper takes a stylized paradoxical fact ${ }^{2}$ of Iranian politics under the Islamic Republic of Iran as its starting point: the stark confusion between the position and a good portion of the opposition. Such a blurred frontier between 'position' and 'opposition' did not exist during the Shah's regime.

Without the decisive support of non-Islamic organizations, secular intellectuals, and political forces on the ground, the creation of a theocratic regime in Iran and its consolidation could not be realized. The theocrats gained the hegemony in the Gramscian sense of the word by winning the support of non clerics. Gramsci's concern with the Catholic Church and fascism's popular appeal in the civil society led him to stress the importance of the cultural dimension of political struggle in then Italy. In that sense, hegemony is not a question of conquering the coercive arm of the state (political society) through a war of position. It is rather a matter of

\footnotetext{
1 Mehrdad Vahabi would like to thank all the participants of the International conference on Retreat of the Secular? Challenges of Religious Fundamentalism, May $1^{\text {st }}-3^{\text {rd }}, 2009$, York University, Toronto for their constructive and useful comments on a preliminary reflection about this issue, see Mehrdad Vahabi, "Islamic Republic of Iran, Clerics and Non Clerics: Who is the Opposition?" (paper presented at the International conference on Retreat of the Secular? Challenges of Religious Fundamentalism, York University, Toronto, 1-3 May, 2009), http://www.yorksecularism.com/

2 The term "stylized facts" was coined by the economist Kaldor in the context of a debate on economic growth. A stylized fact is a simplified presentation of an empirical relationship which lasts for a certain period of time. See Nicholas Kaldor, "Capital Accumulation and Economic Growth", in The Theory of Capital, dir. F. Lutz and D. Hague (London: Macmillan, 1961), 177-222.
} 
winning the "cultural" battle in civil society through a war of attrition. To put it in Gramsci's own words, "It should be remembered that the general notion of state includes elements which need to be referred back to the notion of civil society (in the sense that one might say that state $=$ political society + civil society), in other words hegemony protected by the armour of coercion." ${ }^{3}$ Interestingly enough the Iranian Shi' ite clergy first gained hegemony in the civil society and then conquered the coercive apparatus of the state.

Now in the thirtieth anniversary of the Islamic Republic, the open opposition of many influential clergies towards the way in which government is run under the present Supreme Leader and President Ahmadinejad, provides a new episode of 'opposition' within the theocrats' circles. One of the latest salient illustrations are accusations against the instigators of "soft" or "velvet revolution" in Iran in the aftermath of the so-called presidential "elections" 4 . The list of "instigators" is long: Mir Hossein Mousavi (the ex-prime minister during Ali Khamenei's presidency (1985-1989), Mehdi Karoubi (the spokesman of the sixth parliament), Mohammad Khatami (the ex-president during the years 1997-2005), Ali Akbar Hashemi Rafsanjani (the ex-president during 1989-1997, the present chair of the Assembly of Experts and the Expediency Council) and all the political formations with ties to the above mentioned figures. In fact, a good number of eminent political figures of the thirty years of the Republic Islamic of Iran are now considered as renegades. Conversely, one wonders

\footnotetext{
3 Antonio Gramsci, Selections from the Prison Notebooks, Edited and translated by Q. Hoare and G. Smith, (New York: International Publishers, 1980), 263.

${ }^{4}$ The electoral fraud of June 2009, mainly orchestrated by the Islamic Revolutionary Guards Corp (IRGC) and the Basijis paramilitary volunteer force, was massive as demonstrated in two recent statistical reports by Ali Ansari, Daniel Berman, and Thomas Rintoul, Preliminary Analysis of the Voting Figures in Iran's 2009 Presidential Election (Chatham House and the Institute of Iranian Studies: University of St Andrews, 21 June 2009) and Walter R. Mebane, Note on the Presidential Election in Iran, June 2009 (Michigan: University of Michigan, June 29, 2009). A somewhat similar massive electoral fraud occurred during the ninth presidential elections in June 2005 and the eight parliamentary elections in March 2008, see Ali Alfoneh, «Iran's Parliamentary Elections and the Revolutionary Guards' Creeping Coup d'Etat", American Enterprise Institute for Public Policy Research (AEI), no. 2 (2008). Massive electoral fraud is an appropriate barometer of the increasing influential role of the IRGC and Basijis.
} 
whether Ahmadinejad and the major political force behind him, namely the Islamic Revolutionary Guards Corp (IRGC), are not replacing the Islamic Republic for an Islamic Military government.

To put this paradoxical fact differently, it should be emphasized that no regime in Iran's modern history has produced so much 'opposition' within its own ranks and enjoyed the loyalty of its 'oppositions' at the same time. How could this paradox be explained?

\section{Emergence of Shi'ism as a political force}

It was with the rise of Shah Ismail the first (1501- 1524) and the foundation of the Safavid Empire that the Ithna 'Ashari, or "Twelver" form of Shi' ism was established as State religion in $\operatorname{Iran}^{5}$. Facing a predominantly Sunni society, the new rulers had to import Shi'ite theologians from other Islamic lands to spread the new creed and lay the juridical foundation of the emerging state. The accomplishment of this mission in a span of two hundred years, brought into existence an entirely new social strata in the Iranian society, that of the "ulama, the Iranian Shi' ite clergy.

The downfall of the Safavid (1722) and the disintegration of central power did not result in the dissolution of the Iran's Shi'ite clergy. They survived anarchy and resisted the animosity of Nader Shah, founder of Afshar'id dynasty (1736-60) who discarded Shi'ism as state religion and adopted for Sunni Islam. They also survived the anti-clerical policy of Karim Khan Zand (1705-79) who demanded their participation in productive processes.

\footnotetext{
${ }^{5}$ Roger Savory, Iran under the Safavids (Cambridge: Cambridge University Press, [1980] 2007), chap. 2.
} 
The advent of Qajars (1796) was a turning point in the social existence of Iranian Shi' ite clergy. Besides the Madrasas (traditional schools), an array of judicial and legal functions as well as charity endowments were administrated by the "ulama". Their cooperation with the state during the first Perso-Russian war of 1811-13, improved their ranks in the socio-political structure $^{7}$. Their all out participation in the civil war against the Babi Movement (1848-50) raised them to prominence ${ }^{8}$. As Amir Arjomand correctly states: “(...)from the last decades of the eighteenth century onward, the autonomy of the Shi' ite hierocracy made an alliance with civil society- with urban guildsmen, merchants and shopkeepers- possible and likely. In the last quarter of the nineteenth century, an enduring alliance against the state between mosque and bazaar came into being. Against the background of noticeable growth of the economic power of civil society, this alliance was cemented by the common opposition of the two parties to foreign penetration that resulted from the political privileges and economic concessions granted to imperialist powers by a servile state." 9

As such, long before the conquest of state power, these forces were influential in the public arena and instrumental in the pre-capitalist segment of the civil society. The main issue is then to grasp the role of the Shi' ite hierocracy as a source of social integration.

\footnotetext{
${ }^{6}$ Nikkie Keddie, Roots of Revolution: An Interpretive History of Modern Iran (New Haven and London: Yale University, 1981).

${ }^{7}$ Amir Arjomand, The Turban for the Crown: The Islamic Revolution in Iran (New York: Oxford University Press, 1988).

${ }^{8}$ Abbas Amanat, Resurrection and Renewal: the Making of the Babi Movement in Iran, 1844-1850 (Ithaca, N.Y.: Cornell University Press, 1989).

${ }^{9}$ Ibid., 15. 


\section{Religious hierarchy and Polanyi's triad}

Karl Polanyi's triad ${ }^{10}$ regarding various forms of social integration, namely reciprocity, redistribution and exchange might be an appropriate venue to tackle this problem. Compared to other theoretical frameworks in which productive logic occupies pride of place ${ }^{11}$, Polanyi's "transaction modes" are more appealing in comprehending Iranian contemporary history, given the importance of rentier state based on petrol revenue and authoritarian institutions ${ }^{12}$. The underdeveloped character of the industrial or productive sector has accordingly been related to 'the Dutch Disease'.

Polanyi's three main typical or ideal forms of social integration can be summarized as follows.

1) Reciprocity relates to an overarching social pattern and differs from modern usage of the term that refers to bi-lateral interaction. It assumes another specific institution as background; namely symmetrically arranged groupings such as a kinship system. Individuals as members of a tribe, a clan, a family or religious community often identify themselves with the group and their adherence to rules constitutes the code of honour.

2) Redistribution hinges upon the presence of some measures of centricity in the group like the state or religious hierarchy, and designates movements of appropriations towards a centre and away from it.

\footnotetext{
${ }^{10}$ Karl Polanyi, The Great Transformation (New York: Farrar and Rinehart, 1944); and Karl Polanyi, Primitive, Archaic and Modern Economies (New York: Doubleday, 1968).

${ }^{11}$ See Nazih N. Ayubi, Over-stating the Arab State, Politics and Society in the Middle East (New York: I.B. Tauris Publishers, 1995).

12 Homa Katouzian, The Political Economy of Modern Iran Despotism and Pseudo-Modernism, 1926-1979 (London: The Macmillan Press, 1981).
} 
3) Exchange requires a specific institution, namely archaic markets, or a system of modern price-making markets.

It becomes clear that religious hierarchy has played an important role in both reciprocity and redistribution. For instance, the religious hierarchy in ancient Egypt constituted a centre through which the redistributive mechanism became functional in fields such as social insurance, education and social obedience. Similarly, the Christian Roman church provided a central bureaucracy, a hierarchical educational system as well as a social insurance in the midst of a fragmented political order in Western Europe. It was not by accident that in the old continent, the secular movement advocated both the separation of the state from church, and the separation of the two important institutions of the civil society notably the education and health systems, from the church. The Christian church as a mega institution has extensively contributed to another form of social integration, namely reciprocity through the internalization of informal rules of conduct, traditions and customs.

\section{The Shi'ite hierarchy and the Central State}

Unlike the Christian Roman church, the Shi'ite hierarchy in Iran was not a source of a unified central administration. The central government played a primary role in originating certain social classes and safeguarding property relations. Yet the modernization of state apparatus and the transformation of the traditional army into a standing army came gradually during the period (1796-1925) as the 'Ulama, a faction of the courtiers, the nobility and tribal lords resisted any radical change ${ }^{13}$. Their resistance and outright rejection of any measure towards modernization and capitalist development retarded the growth of the bourgeoisie which had to

\footnotetext{
${ }^{13}$ See Stephanie Cronin, The Army and the Creation of the Pahlavi State in Iran, 1910-1926 (London: Taurus Academic Studies, 1997).
} 
face the challenge of foreign capital at the same instance. The dwindling economic power of the latter and increasing dependency of the corrupt, arbitrary and tyrannical state on Tsarist Russia and Great Britain at the end of the $19^{\text {th }}$ century changed the configuration of forces on the ground. Resentment against Mozaffar al-Din Shah's (1905-1906) autocratic rule reached a point where an amalgam of pre-modern and modern forces joined ranks.

The Constitutional Revolution (1905-09) created the Majles (parliament), introduced legislation, ratified the constitution, instigated a form of parliamentary democracy and curtailed the power and authority of monarch. Yet it also stipulated that "the official religion of Iran is Islam of Twelver Shi' ia and that the king must be a believer in this religion and propagator of it." Moreover, article 27 of the constitution concedes “(...) that no law can be ratified if in disagreement with Islam". To insure this, article 2 of the supplement "calls for the formation of a permanent council of five Mojtaheds [doctors of jurisprudence] to review all the laws before their passage."14

It is important to note that emphasis on Shi' ite Islam and the role of Mojtaheds in overseeing legislation did not appease the Islamic fundamentalists who opposed the very principle of the Constitution and called for the implementation of the Shari'a (the sacred law). The intrigues of courtiers against the nascent order under the auspices of Mohammad Ali Shah, the bombardment of the Majles by the Shah's private Russian led army, the Cossacks (1908) and the restoration of autocracy could not come without the active support of the most eminent Mojtahed of Tehran, Shaikh Fazlullah Nouri and his followers.

\footnotetext{
${ }^{14}$ Mangol Bayat, Iran's First Revolution: Shi'ism and the Constitutional Revolution of 1905-1909 (New York: Oxford University Press, 1991), 262.
} 


\section{Absence of a Secular Discourse}

"The constitution of 1906 and the Supplementary Constitutional Laws of 1907 (...) established the principle of the sovereignty of the nation, but the Majles was unable to institute the separation of religion and state. Instead the new supplementary laws became a vehicle through which the Shi' ite 'ulama safeguarded their institutional and ideological domination within the new political order..."15 that was established after the armed insurrection of the constitutionalists, the deposition of Mohammad Ali Shah and the crowning of Ahmad, his twelve year son.

The question is then why the secular intelligentsia and the non-religious party could not develop a secular discourse, shied away from disengaging the Shari'a from the Constitution of a modern state in a multi-religious society and not fought for the separation of religion and State? Unlike European and American enlightened intellectuals, Iran's progressive forces argued for the compatibility of principles of Modernity (Reason, Science, progress, liberty and modern democracy) with the Shari'a. Like Latin Europe, radical elements of intelligentsia in Iran waged a vehement struggle against the Clergy. Led by A.K. Dehkhoda and the journal Sur-e Israfil they were labelled ulama-ye su (false 'ulama) or tojjar-e din (traders in religion) "who have no purpose than the cult of the self and love of leadership". But even Dehkhoda, took refuge in religion, when attacked by the reactionary forces, proclaiming that the "true Islam" is totally different from that of the "ulama who have obscured the true spirit of Islam and created a theology which is nothing more than a concoction of "Greek, Indian, Chaldean and Jewish nonsense." 16

\footnotetext{
${ }^{15}$ Janet Afary, The Iranian Constitutional Revolution 1906-1911 (New York: Columbia University Press, 1996), 89.

${ }^{16}$ Bayat, Ibid., 170. 


\section{Secularism from above}

The British backed coup d'état of Feb $1921^{17}$, the rise of Cossack army commander Reza Khan to power and his eventual coronation in October 1925, the dethronement of Ahmad Shah and the fall of Qajar dynasty, paved the way for the rapid implementation of a modernization program long desired by progressive constitutionalists ${ }^{18}$. The modernization model designed by a new generation of young western educated intelligentsia along with a few pragmatic veterans of constitutionalist movement had at its core the formation of a modern unified army, the creation of a central government and an efficient bureaucracy, the expansion of new educational facilities, the settlement of nomadic tribes and their transformation to farmers as well as the construction of the infra-structure conducive for capitalist development of the country. The "New order" which rejected republic, democracy, free circulation of information, freedom of expression, critical thought and religious reformation, was initially blessed by the "ulama.

Soon after the consolidation of Reza Shah Pahlavi at the top of the power pyramid, Constitutional Monarchy gave way to absolute Monarchy and a new autocracy. Determined to implement the pseudo-modernist program with the iron fist of the state, Reza Shah wrested control of public education, administration of justice and legal matters from the clergy, bestowing it on the hands of the state. His limited, piecemeal secularism from the above was neither accompanied with anti-clerical campaign nor with the disentanglement of sacred from profane, "the religious and the temporal.",19

\footnotetext{
${ }^{17}$ Nikkie Keddie, Qajar Iran and the Rise of Reza Shah (1796-1925) (California: Mazda Publishers, 1999); and Cyrus Ghani, Iran and the Rise of Reza Shah (London, New York: I.B. Tauris, 2000).

${ }^{18}$ Ervand Abrahamian, Iran between the Two Revolutions (New Jersey: Princeton University Press, 1982).

${ }^{19}$ Bayat, Ibid., 9. 
The invasion of Iran in August 1941, the forced abdication of Reza shah by the Allies, the enthronement of young Mohammad Reza, the collapse of the old order and the growing involvement of all classes in political process, the restoration of democracy, civil rights and socio-political freedoms, ushered in a new area. Frightened by the "spectre of communism" the court embarked upon supporting religious institutions in its "Crusade" against spectrum of "infidels" ${ }^{20}$. Faced with the growing threat of a new dictatorship, the democratic forces forged an alliance against the Islamists who finally changed camp and supported Mohammad Reza Shah in August 1953 CIA- MI6 coup d'état against the government of Dr. Mossadegh ${ }^{21}$.

The holy alliance against the Mossadeghists and the pro Soviet Stalinist Tudeh party, did not last long. They were warned to stay away from the political process and banished to Seminaries. The increasing dependency of Shah Mohammad Reza Pahlavi on the US, the entrenchment of Iran in the Capitalist World System and its responsiveness to the directives of its leading institutions, the necessities of capitalist development and the need to undertake preventative measures against the possibility of a Communist lead revolution, persuaded the Shah to launch the "White Revolution" the kernel of which was the land Reform program. Shah's agrarian reforms led to the massive urbanization of peasants, making them the labour force of the pseudo-modernization program crowned by Reza Shah and now continued by his son.

Sidelining of the Shi' ite clergy and dispossessing them of their last prerogative- religious endowments- once again threw the clergy into the ranks of the opposition. Making the rendez-

\footnotetext{
20 Nasser Mohajer, "The Stabbing to Death of Dr. Berjis" , Baran (A Persian Quarterly on Culture, Literature, History and Politics, Sweden), nos. 19-20 (2008).

${ }^{21}$ Nasser Mohajer, "Yesterday and Today", Azadi (A Persian Language Quarterly on Politics, History and Culture published in London), nos. 26\&27 (2005).
} 
vous of history, Ayatollah Khomeini led the revolt of pre-capitalist social classes who conceived the white Revolution as their death nail. The 1963 June $5^{\text {th }}$ uprising of the traditional urban petite-bourgeoisie, bazaar merchants, declassified city dwellers and the lumpen-bourgeoisie, backed by ex-landowners and disgruntled members of the old ruling class, changed the image of the shi'ite clergy in the eyes of the progressive opposition and dissident intellectuals in struggle against an omnipotent western-oriented autocracy ${ }^{22}$. The remnants of the national bourgeoisie and the traditional bazaar merchants needed Islamic clergies in opposing foreign capital and restraining the power of a despotic monarch. Hence in Iranian modern history, Shi' ite Islam represented anti-communism, anti-colonialism and later on anti-imperialism in the name of religion and tradition. Examining the relationship between the clergy, nationalists, and the left movement in almost all decisive periods of struggle against monarchical rule, shows that the non cleric forces have retreated from secular demands in the name of 'unity' with 'progressive', and /or 'anti-imperialist militant Islam' in fear of losing the support of people. In this respect, years before Foucault's fascination with Khomeini $^{23}$, intellectuals such as Al Ahmad praised the Shi'ite clergies for defending authentic Iranian nativism against the penetration and prevalence of Western cultural values. Thus, the weakness of the national and industrial bourgeoisie, and the dependency of the authoritarian regime on the US led to the reproduction of a limited, piecemeal secularism from above leaving Islamists to re-emerge as a hegemonic force in the public life. As mentioned earlier, despite pockets of secular circles, there has never been a truly secular

\footnotetext{
22 Nasser Mohajer, “Towards Power”, Nogtheh (A Persian Language Quarterly on Politics, History and Culture published in Paris), nos.4\&5 (1996).

${ }^{23}$ See Janet Afary and Kevin Anderson, Foucault and the Iranian Revolution, Gender and the Seductions of Islamism (Chicago and London: Chicago University Press, 2005).
} 
movement in the recent Iranian history. Their ever-increasing "anti-imperialist" slogans were welcomed by the leading intellectual of the time, Jalal Al-e Ahmad, many leaders of the National Front and the Tudeh Party. The imprisonment and forced exile of Ayatollah Khomeini strengthened-position of now the "militant clergy" in a society in crisis and need of a fundamental change.

\section{Parallel institutions and destructive coordination}

The conquest of the political power by a political block led by a clique of Shi' ite clergies was a new phase in the role of religious hierarchy in social integration and /or disintegration in Iran. Although, according to Polanyi, "redistribution" could be managed either by a central state authority or a religious hierarchy, the traditional Shi' ite religious structure could not be a source of centralization in post-revolutionary Iran.

The Shi'ite traditional hierarchy is polycentric. The principle of Ejtihad (the competence of the jurists to derive new legal norms from the sources of the "sacred law") associated with the Shi' ite Twelvers' jurisprudence, connotes the process of making a legal decision by independent interpretation of the legal sources, the Qur'an and the Sunnah (prophetic tradition). The opposite of Ijtihad is Taqlid or imitation. The masses of the community of the believers' should imitate a Marja Taqlid (literally meaning source of emulation). Because of the permissibility of free interpretation of legal sources, Shi' ism acknowledges many sources of emulation. Every shi'ite has the freedom to choose his/her own Marja Taqlid ${ }^{24}$. This leads

\footnotetext{
${ }^{24}$ See Linda S. Walbridge (ed.), The Most Learned of the Shi'a: The Institution of the Marja 'Taqlid' (Oxford: Oxford University Press, 2001).
} 
to a polycentric hierarchy which is a structural hindrance to a unified state religion and a centralized state hierarchy ${ }^{25}$.

In fact, from its inception, the Islamic Republic of Iran was founded on an antagonistic relationship between a centralized bureaucratic and military state apparatus and the traditional Shi' ite hierarchy. The outcome was a system of parallel institutions that spread all over social life in its various political, economic, and cultural aspects. The overarching character of parallel institutions is a salient symptom of state failure which provides the ground for the foundation of destructive coordination.

Following Polanyi's triad, Vahabi identifies a new or fourth type of social integration which he dubs integration through coercion or destructive coordination ${ }^{26}$. A simple illustration of destructive coordination in comparison with other forms of social integration is provided by the way different types of prisons are coordinated ${ }^{27}$.

Redistribution (bureaucratic coordination) is common in military prisons for national soldiers and officers charged for misconduct. In this type of prison, the relationships among prisoners and between prisoners and guards are regulated by official prescriptions and strict administrative regulations.

\footnotetext{
${ }^{25}$ It is noteworthy that nationality is not a criterion in choosing a source of emulation. This pre-modern cosmopolitism is in tune with the ambition of the leaders of the Islamic Republic of Iran for expansion and exportation of Islamic Revolution. However, this contradicts the requirement of national identity for ruling within a state.

26 For a theoretical formulation of the concept see Mehrdad Vahabi, "An Introduction to Destructive Coordination", American Journal of Economics and Sociology, Vol. 68, no. 2 (2009a), 353-386. For an application of the concept to Iran and other countries, see Mehrdad Vahabi, "Between Social Order and Disorder: The Destructive Mode of Coordination", Working Paper, Munich Personal Repec Archive (2006), http://mpra.ub.uni-muenchen.de/; and Mehrdad Vahabi, "Ordres contradictoires et coordination destructive : le malaise iranien”, Revue Canadienne d'Etudes du Développement (Canadian Journal of Development Studies) Vol. 30, nos. 3-4, (2010), 503-534.
}

${ }^{27}$ See Mehrdad Vahabi (2009a) for a formalized version of this example in terms of game theory and a detailed discussion of other illustrations of destructive coordination (traffic circles and blood transfusion). 
Reciprocity usually prevails in political prisons under authoritarian or totalitarian regimes. Political prisoners look after each other particularly when one falls ill or is severely tortured. Prisoners act collectively to display their distinct identity as 'political' opponents of the regime and boost their morale against the prison authorities who continuously try to crush their resistance ${ }^{28}$.

Exchange (Market coordination) is used in case of affluent or renowned prisoners (like Paris Hilton) in ordinary or criminal prisons who can bargain for special treatment and protection with guardians against monetary rewards. Privatisation of prisons or their management can strengthen this kind of coordination ${ }^{29}$.

Destructive coordination is the dominant form of coordination in many criminal public prisons throughout the world. A more general philosophical reflection concerning modern 'prison' as the continuation of medieval dungeon for 'surveillance and punishment ${ }^{30}$ reveals the destructive nature of the institution in itself ${ }^{31}$.

One can hardly argue with Foucault and Deleuze in their description of destructive dimensions of Prison. Yet, we refer to destructive coordination in a more specific way. It is based on the predominance of violence in the relationship between guards and prisoners as well as among prisoners themselves. Accordingly, the 'law of the jungle' reigns among the

\footnotetext{
${ }^{28}$ Nasser Mohajer (ed.), The Book of Prison. An Anthology of Prison Life in the Islamic Republic of Iran, 2 Volumes (Berkeley: Noghteh Books, 2001).

${ }^{29}$ Angela Davis, Are Prisons Obsolete? (New York: Seven Stories Press, 2003).

${ }^{30}$ See Michel Foucault, Surveiller et punir (Paris: Gallimard, 1975), and Gilles Deleuze, "Post-scriptum sur les sociétés de contrôle », in Pourparlers (Paris: Minuit, 1996), 240-247.

31 There are also situations in which a mixture of different modes of coordination is at work. In the absence of a political prison for example, when, political prisoners as well as military convicts are kept in jail with delinquents under military supervision, see Fyodor Dostoyevsky, The House of the Dead (London: Penguin Books, [1861-62] 2003).
} 
various gangs of prisoners, particularly when governors and guards start mistreat them. While the practices employed in Guantanamo is considered illegal on US soil, they were authorized by an appeal to a 'state of emergency' ${ }^{32}$, yet the results of detailed investigations on prisons in the United States and France reveals that "every prison has its own Guantanamo",33. Nevertheless, the 'jungle' has its own 'codes and laws', and one of its inviolable articles is what we find amongst the Mafia: "It is a fundamental rule for every man of honour never to report a theft or crime to the police." 34

In the absence of 'public' protection, aggressive behaviour permeates all relationships among prisoners. Even when an inmate is confronted with an aggressive prisoner, it is advisable to act aggressively and accept the cost of giving a 'signal' for not being considered a coward. Everyone fares better in seeking 'private' protection by joining a 'gang'. Retaliation emerges, thus, as a way to regulate conflicts. Costly 'signalling' and creating the 'reputation' of being a 'tough guy' is a prerequisite of rendering one's threat credible. Peace between prisoners is then nothing but a 'balance of terror'.

One can note that in the above mentioned example, destructive coordination is closely linked to the nature of prison as a social institution that destroys the vital space of individuals. Apart from this fundamental institutional failure, the lack of 'public' protection and the need for 'private' protection nurture destructive coordination. The perpetuation of this type of coordination is thus related to the state failure within prisons. It justifies the existence of

\footnotetext{
32 Giorgio Agamben, State of Exception (Chicago and London: Chicago University Press, 2005).

${ }^{33}$ Laurent Mouloud, “Chaque prison a son petit Guantanamo..., » l'Humanité, 21 December 2006.

${ }^{34}$ Diego Gambetta, The Sicilian Mafia (Cambridge, Mass.: Harvard University Press, 1996), 119.
} 
gangs and guarantees compliance to the 'parallel' codes of prisoners. It also requires the permanent use of direct coercive means to guarantee the unstable dominance of one powerful group over others. It achieves coordination through intimidation, threat, and the use of coercive means. This type of coordination is located between social order and anarchy. The social order under the Islamic Republic of Iran is the emblematic illustration of destructive coordination $^{35}$.

\section{Constitutional and military theocracy}

The seizure of power by theocrats has led to major changes in the Shi'ite traditional hierarchy ${ }^{36}$. First of all, the control of theocrats over a rentier state warrants their financial independence from their traditional sources of revenue (Xoms and Zekat). They thus have become not only financially independent, but have also created new praetorian layers under their patronage. The jurisconsult of supreme leader (Velayat Faqih) ${ }^{37}$ forms a state religion in which political considerations over religious priorities are sealed under the title of absolute power of the jurisconsult. This new authority leans more on its new military power than on the clergy.

\footnotetext{
${ }^{35}$ The fact that Islamic prisons reflect the ideal social order that the leaders of the Islamic Republic endeavour to build is noted by many authors. A recent article entitled "Theology of Torture" by Nikfar further explores the issue. See Mohammad Reza Nikfar, "Elahyat Shekanjeh" (Theology of Torture), 2 September 2009, www.akhbar-rooz.com

${ }^{36}$ Mehdi Khalaji, “The New Order of Clerical Establishment in Iran”, Iran Nameh, Vol. XXIV, nos. 2-3 (2008), 305-338.

37 The institution of Velayat-e-faqih or guardianship of the jurisconsult is Ayatollah Ruhollah Khomeini's legacy to Shi' ite political theory and praxis. "The jurisconsult, or supreme leader, is a highly esteemed cleric chosen by his peers on the eighty-six-member Assembly of Experts in recognition of his knowledge of fiqh, or Islamic jurisprudence, and his other religiopolitical credentials. The Supreme Leader's role is to guide Iranians (and, in theory, other Muslims) toward the just government of God. His powers are wide ranging. He is the Commander-in-chief of Iran's armed forces, may veto the President's decisions, and is charged with protecting the government's Islamic character » Bahman Bakhtiari, "Dilemmas of Reform and Democracy in the Islamic Republic of Iran", in Remaking Muslim Politics: Pluralism, Contestation, Democratization, ed., Robert Hefner, (Princeton: Princeton University Press, 2005), 114.
} 
The natural evolution of the Islamic Republic of Iran embraces two apparently opposing but complementary tendencies: 1) A Praetorian theocracy; 2) A constitutional theocracy. The first has increasingly relied on the ascending Military-Industrial Complex managed by the Revolutionary Guards (IRGC) and the Para-military Basijis in consultancy with the Supreme Leader. This tendency insists on "Islamic governance" and discards its "republican" aspect. The second tendency is supported by some of the old guards and close disciples of Ayatollah Khomeini, now in opposition, who draw their legitimacy from the polycentric Shi'ite traditional hierarchy as well as the "Islamic civil society".

Interestingly enough, the concept of civil society which was reintroduced into the lexicon of political scientists in the West after the collapse of the Soviet Union and the rise of prodemocracy movements in Eastern Europe was borrowed by the Islamic reformists in Iran after the end of Iran-Iraq war (1980-1988). It was the reformer Islamic philosopher, Abdolkarim Soroush, who coined the controversial and convoluted concept of "Islamic civil society" under the presidency of Hashemi Rafsanjani ${ }^{38}$. The idea turned into a working project by the ex-security chief Saeed Hajarian and his team (mostly in prison now after the rigged election of June 2009) in the Center of Strategic Studies with the aim of reconstructing the hegemony of the Islamic forces in the civil society. Instead of reducing the Islamic state to its violent coercive apparatus, this project promoted Islamic women, teachers' and students' associations, Islamic workers and peasants' organizations, and a variety of NGOs to build new bridges with the civil society. "Islamic civil society" was envisaged to lengthen the life expectancy of the regime as a constitutional theocracy.

\footnotetext{
${ }^{38}$ For a more detailed discussion regarding Islamic political notions and civil society, see Sohail H. Hashmi (ed.), Islamic Political Ethics: Civil Society, Pluralism, and Conflict (Princeton: Princeton University Press, 2002); and Mohammed Hashim Kamali, "Civil Society and Islam: A Sociological Perspective", European Journal of Sociology, Vol. 42, no. 3 (2001), 457-482.
} 
In this spirit, partisans of military theocracy are at times depicted as an 'opposition' force against the old guard, whereas the old guard are portrayed as an 'opposition' force against the absolute power of the supreme leader. A constitutional theocracy is then presented as the formal opposition to military theocracy. The advocates of constitutional theocracy vindicate "Islamic Republic" as it was during the supreme guardianship of Ayatollah Khomeini and argue against reducing it either to a form of "Islamic governance" or transforming it into a "Republic".

As Mousavi, the ex-prime minister and thwarted presidential candidate in the recent fraudulent election reminded street demonstrators in Tehran: "we want 'Islamic Republic', nothing less, nothing more". He, thus, repeated the slogan of Khomeini, the founder of the Islamic Republic on the morrow of Iranian revolution of 1979.

But what is meant by "Republic" in the constitution of Iran's Islamic Republic? If by "Republic", one means a modern democratic form of state based on the sovereignty of people, universal suffrage, and separation of executive, legislative and juridical powers, then Islamic Republic is obviously an oxymoron". However, if "Republic" is understood in the premodern sense of the term referring to a council-based as opposed to monarchical governments $^{40}$, then the Islamic Republic of Iran is a justified term to depict a pluralist decision-making system within the partisans of Velayat Faqih. This oligarchic pluralism is compatible with the traditional Shi'ite polycentric structure.

\footnotetext{
39 Asghar Schirazi, The Constitution of Iran: Politics and the State in the Islamic Republic (London, New York: Tauris, 1997).

40 William R. Everdell, The End of Kings: A History of Republics and Republicans (Chicago: Chicago University Press, 2000).
} 
The active intervention of the IRGC and the Basijis in Iran's economy and politics undermines the notion of "Republic" in its limited pre-modern sense of the word. When the rentier position of major representatives of Shi'ite oligarchy such as Rafsanjani, Tabasi, and their cronies are menaced by the ascending position of the $\mathrm{IRGC}^{41}$, and when the rivalry amongst different factions of the Islamic Republic is not decided through electoral means, inevitably the pillars of the "Islamic Republic" are pushed into "opposition".

The economic aspect of this conflict should particularly be stressed, since the allocation of resources in destructive coordination is based on appropriative or predatory activities. Traditional merchants and the petite-bourgeoisie (Bazaaris) were the life blood of the Shi' ite clergy before the 1979 revolution. After the revolution, the hegemonic position of Shi' ite clergy in the state led to the formation of Bonyads (Islamic economic foundations). The postrevolutionary Iran has been witnessing the dominance of destructive coordination with Bonyads as its particular economic institution.

Bonyads are regarded as 'para-governmental ${ }^{42}$, or 'para-statal foundations' ${ }^{43}$. There exists a great variety of Bonyads among which Bonyad-e Mostazafan va Janbazan (BMJ, Foundation of the Oppressed and Self-Sacrificers) and Bonyad-e Shahid (Martyrs' Foundation) are the most prominent. The BMJ was set up after the confiscation of the assets of the late

\footnotetext{
${ }^{41}$ See Frederic Wehrey, Jerrold D. Green, Brian Nichiporuk, Alireza Nader, Lydia Hansell, Rasool Nafisi, and S. R. Bohandy, The Rise of the Pasdaran, Assessing the Domestic Roles of Iran's Islamic Revolutionary Guards Corps (Rand National Defense Research Institute, Prepared for the Office of the Secretary of Defense, 2009) and Ray Takeyeh, Guardians of the Revolution, Iran and the World in the Age of the Ayatollahs (New York: Oxford University Press, 2009).

42 Ali Saeidi, "The Accountability of Para-governmental Organizations (bonyads): The Case of Iranian Foundations", Iranian Studies, Vol. 37, n 3 (2004), 479-498.

${ }^{43}$ Suzanne Maloney, "Agents or obstacles? Parastatal foundations and Challenges for Iranian development", in The economy of Iran: The dilemma of an Islamic State, ed. Parvin Alizadeh, (London, New York: I.B. Tauris Publishers, 2000), 145-176.
} 
Mohammad Reza Shah and 53 industrialists in the aftermath of the revolution. This was done in conformity with Khomeini's injunction which categorized these assets 'spoils' and added that 'they must be kept and controlled separately from state properties' ${ }^{44}$.

The size and scope of the BMJ is similar to that of a State. With holdings worth 12 billion US dollars, the BMJ constitutes the largest non-state sector in the economy, second only to the National Iranian Oil Company in size. Although there is no accurate information about Bonyad's activities due to total opacity, the recent economic report of the French Embassy in Tehran estimates that its different branches contribute from $7 \%$ to $10 \%$ of the Iranian GDP ${ }^{45}$. The BMJ operates like a holding with many enterprises extending almost in all sectors of the economy such as mining, housing, manufacturing, trade, shipping, transportation, airline, tourism, agriculture, food industry and soft beverages. Recently, it has been strengthening its position in the energy and communication sectors ${ }^{46}$.

At the outset the Bonyads were acting mainly as authoritative financial resources of Shi' ite clergy and Bazaar merchants. But not long after the Iran-Iraq War, the IRGC also began its industrial and profit-making undertakings. In fact, President Rafsanjani's government encouraged the IRGC to use economic activities to bolster its budget. The corps took control of several confiscated factories and established the moavenat khod-kafaee (headquarters of self sufficiency) and moavenat bazsazi (headquarters of reconstruction). In 1990, the headquarters became the famous firm Khatam al-Anbia. The firm has been awarded more than 750 contracts in various construction, infrastructure, oil, and gas projects. Apart from its

\footnotetext{
${ }^{44}$ Saeidi, Ibid., 484.

45 Ambassade de France en Iran, Bonyad Mostazafan : La Fondation des déshérités en Iran (Tehran : Fiche de Synthèse, Mission Economique 20 June 2006).

${ }^{46}$ See Vahabi, 2006, Ibid. and Vahabi, 2010, Ibid.
} 
declared enterprises, the IRGC is reported to control an underground shadow economy of black-market goods, smuggled into Iran via illegal jetties and other entry points under its sole control. The new IRGC's economic empire aspires to get rid of the clergy's grip over Iranian economy and to dominate the Bonyads.

The transformation of Islamic Republic into a military theocracy requires the end of the limited oligarchic pluralism and its Shi'ite Akhabari principle namely Ijtihad. This will be perhaps the victory of the supreme leader and state religion over the polycentric Shi' ite structure. But who will really be in command of the state machine in such a circumstance: the supreme leader or the IRGC and Basijis? Will the heir of the Islamic revolution be its gravedigger?

\section{Conclusion}

June $12^{\text {th }}$ presidential election, the nation-wide protest movement to its fraudulent outcome and official results, the open defiance of defeated candidates and resistance of the entire Reform camp to the dictates of the Supreme Leader and the worldwide solidarity for the "Iranian Opposition" has created an unprecedented crisis for the regime in power. The brutal crackdown of the protest movement(s), the imprisonment, torture and forced confessions of the "outlaws" -some the founding fathers of the Islamic Republic of Iran- and fear of IRGC taking over the state, has drifted the Reform camp to the centre of Iranian opposition.

The toddler secular movement, in spite of its numerical force and untapped capacity, has not been able to play its own independent role in the ongoing show of force as of now. The question is: is pragmatism going to triumph over ideology once again and this time with the real perspective of IRGC taking both the state and economy, or is it the secular current to standout and regain its rightful place in struggle against theocracy and for democracy? The 
deadlock of Iranian politics is closely linked to the absence of a strong secular and democratic voice independent of the 'Islamic civil society'. 